\title{
Teacher Training for Educational Change: The View of International Experts
}

\author{
José Manuel García-Vandewalle García \\ Department of Didactics and School Organization, University of Granada, Spain \\ ORCID: 0000-0001-9309-1703 \\ Marina García-Carmona \\ Department of Didactics and School Organization, University of Granada, Spain \\ ORCID: 0000-0002-5314-5639 \\ Juan Manuel Trujillo Torres \\ Department of Didactics and School Organization, University of Granada, Spain \\ ORCID: 0000-0002-2761-3523 \\ Pablo Moya-Fernández \\ Department of Quantitative Methods for Economics and Business, University of Granada, Spain \\ ORCID: 0000-0003-0980-3849
}

Received: 12 May 2021

Accepted: 15 Sep 2021

\begin{abstract}
Digital competence has become a new type of literacy that significantly impacts on people's lives, as it is paramount to their social and occupational integration. In educational institutions, teachers play a major role in developing the digital skills of their students. This study aims to determine the key elements of teacher training in the use of innovative technologies and methodologies with a view to providing alternatives to improve the educational process. The objective is to overcome deficiencies in the training of teachers in new technologies and innovative methodologies. A qualitative study based on interview data is used in two phases. For the first phase research, semi-structured interviews were conducted with eight international education experts from various fields on how best to train teachers. The second phase research involved a text mining analysis of the interview transcripts based on sentiment analysis and word counts using the advanced $\mathrm{R}$ statistical programming language. The second phase research was conducted using the $R$ statistical programming language. The interview transcripts were analysed using sentiment analysis and a word cloud. The results reveal that teacher education should be practice-focused and supervised by senior teachers with the aid of students and heads of schools. Moreover, standards should be set to monitor the digital competence of teachers, who should be trained on an ongoing basis to keep them up to date in the use of digital technologies.
\end{abstract}

Keywords: teacher education, teacher training, educational technology, educational innovation, preservice education

\section{INTRODUCTION}

Today, knowledge is fundamental for economic development (Mendonça et al., 2015). In knowledge-based societies, digital literacy is essential to equip learners with the necessary skills to ensure professional and personal success in the 21st century (Hohlfeld et al., 2008). Digital literacy is a core concept in education, not 
only with regard to the acquisition of theoretical knowledge, but also practical experience through problem solving or collaborative work (Baran \& Uygun, 2016; Siddiq et al., 2016), with some authors even supporting the idea that it is as important as being able to read and write (Wilson et al., 2015).

Information and communications technologies (ICTs) are of critical importance to society because they contribute to economic development (Park et al., 2015) and ICT skills are essential for getting a job (Jones \& Pal, 2015). Despite being digital natives, however, the digital competence level of Generation Z (people born from the mid-1990s to the mid-2000s) is low, since mere exposure to these technologies is insufficient and digital literacy depends on how ICTs are used (Pérez-Escoda et al., 2016). In this regard, ICTs can be defined based on three dimensions of use: access to assets (devices), basic skills (knowledge of how the tools work), and complex capabilities (higher-level knowledge, digital literacy) (Mendonça et al., 2015). Yet digital literacy is not simply a question of using technology (Akayoglu et al., 2020; Pérez-Escoda et al., 2016); it requires specific training for the acquisition of complex skills and competencies. For this reason, it is necessary to teach students advanced digital skills with a view to their future labour market insertion.

To this end, it is essential to promote ICT use among students and integrate these technologies in the classroom (Thieman \& Cevallos, 2017). The use of ICTs in the classroom also improves students' academic performance, thus making teaching more effective and boosting the quality of education (Hambira et al., 2017). ICTs also facilitate students' work, give them more autonomy, motivate them, and can be adapted to each student's level regardless of their difficulties (García-Valcárcel et al., 2014).

For instance, ICT training works well for learners with special educational needs and is one of the most useful forms of vocational rehabilitation for people with disabilities (Midgley, 1993), to such an extent that the British government recognised the importance and benefits of ICT use for people with special educational needs (Williams et al., 2006). Moreover, thanks to the Internet, ICTs are a powerful resource that can foster intercultural interaction by supporting different languages and cultures as never before (Resta \& Laferrière, 2015). A direct relationship has also been found between people with access to the Internet and health literacy (Estacio et al., 2017). Additionally, the widespread use of ICTs has had an increasing impact on society and on relations between institutions and citizens (Eger \& Maggipinto, 2010) and does so in an inclusive way because technology enables the full participation in society of people with visual impairments and problems of mobility (Jones \& Pal, 2015).

Emerging technologies will continue to influence our society and are expected to affect education more deeply than ever before (Klaassen et al., 2017). For this reason, it is important that teachers be aware of technological innovations that will improve the future professional performance of their students (Foronda et al., 2017) by helping them to develop vital innovative and creative skills (Klaassen et al., 2017). In doing so, the skills acquired by students will in turn be passed on to society, in addition to encouraging the involvement of parents and family members in the use of technologies (Manzoor, 2016). To ensure the proper integration of ICT in the classroom, it should be viewed as a mode of learning and included in the curriculum (Nikolopoulou \& Gialamas, 2015b).

Therefore, it is essential that teachers be properly trained in order to effectively develop the digital knowledge and skills of their students. The aim of this research is to determine the key elements of teacher training in the use of innovative technologies and methodologies in order to improve the educational process.

\section{Teacher Training}

Teachers are a key element for the integration of technology in the classroom (Geer et al., 2017) because educational success depends largely on them (Nikolopoulou \& Gialamas, 2015a). Exemplary schools and teachers can make a difference (Munns et al., 2013) and when they also use ICTs properly, multiple benefits can be gained, such as greater teacher availability, fewer time constraints, and more personalised learning (Durães et al., 2016). However, many teachers are reluctant to implement ICTs in their classrooms (Van Acker et al., 2013) and use technology very infrequently, resulting in the poor integration of ICTs in the classroom (Marcelo et al., 2015). Normally, when ICTs are employed for teaching purposes, only a limited number of 
resources are used based on traditional methods (Brun \& Hinostroza, 2014) because teachers integrate the technologies that best suit their teaching practices (Marcelo et al., 2015).

Although teachers generally perceive the integration of ICTs in their classrooms in a positive light, they often encounter barriers that prevent them from doing so (Bingimlas, 2009). According to Pelgrum (2001), 40\% of teachers believe that the main obstacle to using ICTs is the lack of digital devices. In Spain, ICT use in the classroom is low, despite the extensive ICT infrastructure in schools (Gil-Flores et al., 2017). In addition to insufficient material, the limited use of ICTs is due to teachers' lack of technical competence, mastery of the technology, and the excessive time and effort involved (Tallvid, 2016). Nikolopoulou and Gialamas (2015a) found that teachers perceive four barriers to ICT use: lack of support, lack of confidence, lack of equipment, and class conditions. Anxiety about using ICTs is one of the main barriers due to teachers' lack of confidence and negative attitudes (Van Acker et al., 2013). Anxiety also occurs because teachers worry that they know less than their students and do not have enough knowledge to solve their doubts (Wang et al., 2014). This happens with new technologies because teachers are sometimes less digitally literate than their students (Cairns \& Malloch, 2017; Wang et al., 2014).

The key to developing students' digital competence is determined by teachers' own digital and pedagogical skills (Fernández-Cruz \& Fernández-Díaz, 2016). Indeed, teachers cannot develop their students' digital competencies if they do not have them themselves (Fernández-Cruz \& Fernández-Díaz, 2016). Because teachers have more pedagogical than technical knowledge-which implies that they have little knowledge to integrate ICTs and develop their students' digital competencies-they need to change their mindset and become digitally literate (Roig-Vila et al., 2015). The digital competence of teachers is essential for the integration of ICTs in the teaching-learning process and these competencies need to be defined in a common framework (Almerich et al., 2016). Therefore, teachers must be properly trained in the use of ICTs, as technologies alone cannot change learning environments (Marcelo et al., 2015).

The most important factors in teacher education are hours of training and support for teachers (Charbonneau-Gowdy, 2015; Hsu \& Kuan, 2013). Continuous teacher training combined with collaborative work with colleagues fosters a positive attitude towards ICT use (Van Acker et al., 2013). However, it is necessary to offer training schemes at times that teachers can attend, as training is often incompatible with their work at school (Cuban et al., 2001).

In the training of future teachers, it is important to instruct them in how to integrate ICTs into the teaching and learning process (Brun \& Hinostroza, 2014) as there is a gap in teacher education between theory and practice due to a lack of experience with innovative methodologies (Barak, 2014). Currently, pre-service teachers have learning experiences with ICT but they are not significant (Valtonen et al., 2015), partly because it is very difficult for teacher training institutions to assist prospective teachers in designing and integrating ICT into their teaching practice (Tondeur et al., 2016). This is a problem because trainee teachers' perceptions of the use of new technologies are conditioned by their previous experiences (Koh et al., 2013). However, when training experiences with ICT are good, teachers succeed in transforming students' worldviews and are more committed to using technology in their classrooms to build collective knowledge (Bozalek et al., 2013). ICT training for heads of schools is also important and should be a priority as it hastens the pace of technology integration in schools (Tondeur et al., 2008).

In terms of support, teachers need to be provided continuous accompaniment and follow-up until they become proficient in the use of technology (Archer et al., 2014), as it is a fundamental aspect of their professional development (Quintana \& Zambrano, 2014). Moreover, given that teacher motivation is one of the most important factors in the integration of ICTs in the classroom (Uluyol \& Sahin, 2016), teachers need to be encouraged to be more open to innovation and use these technologies both inside and outside the classroom (Van Den Beemt \& Diepstraten, 2016).

The role of teacher educators is also crucial to building a solid knowledge base and developing 21st-century skills in teachers (Garba \& Yusuf, 2016). Teacher educators who use ICTs in innovative ways (Drent \& Meelissen, 2008) maintain contacts with educators and ICT experts, observe and experience the benefits of ICTs, use a learner-oriented pedagogical approach, and have a level of digital competence commensurate 


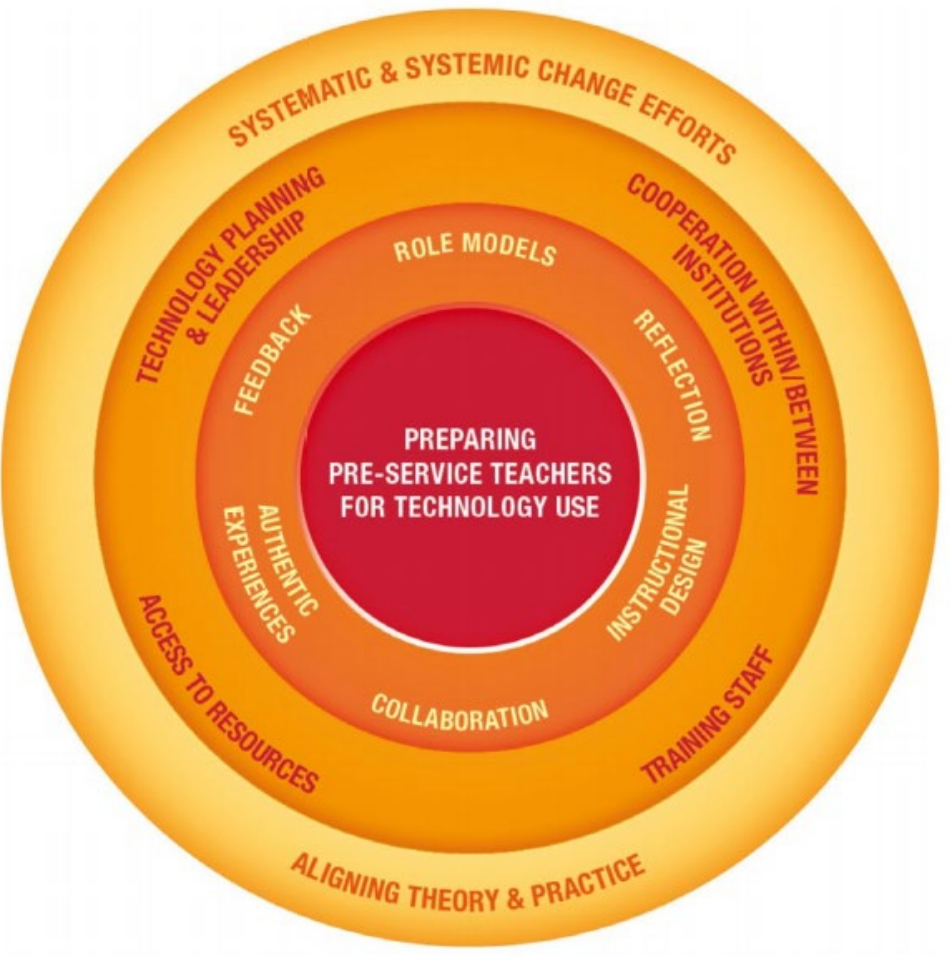

Source: Tondeur et al. (2012) [Colour figure can be viewed at wileyonlinelibrary.com]

Figure 1. SQD model to prepare pre-service teachers for technology use

with their pedagogical expertise. Recent studies conducted with university professors have shown that teacher training has shifted from a teaching paradigm to a learning paradigm (Guillén-Guerrero \& Molina, 2019). Differences have also been found between new teachers who have recevied training and accompaniment (Kozanitis et al., 2018) and those who have undergone a longer training process with respect to those who have not (Postareff et al., 2007). In general, previous research has established a positive relationship between the length of training ( 45 hours) and the evolution of teaching conceptions and approaches (Kozanitis et al., 2018). Similarly, other studies have shown that building a climate of mutual respect and trust among teachers helps to improve their professional competencies and that participation in a learning community reinforces their professional identity (Nemiña, 2018).

Many of the traditional teacher education models are technocentric (Harris et al., 2009). For this reason, the Technological Pedagogical Content Knowledge (TPACK) model is now recommended to ensure that teachers are qualified to meet the requirements of 21st-century learning (Drajati et al., 2021). TPACK can be taught effectively through training courses (Zimmermann, 2021) that can be blended (Guillén-Guerrero \& Molina, 2019). Instruments are also needed to assess TPACK in pre-service teachers (Schmidt et al., 2009). In this line, some studies are presenting very valid ways of assessing the model (Wahyuni et al., 2021). Other strategies have also been employed to prepare pre-service teachers, such as the Synthesis of Qualitative Data (SQD) model (Tondeur et al., 2019), which considers teacher educators as role models, encourages reflections on the role of technology in education, technology use, collaboration with other teachers, supervised experience, and continuous feedback.

Pre-service teacher training in ICT competence occurs in three stages (Chen et al., 2017): cognitive search, activity, and practice. In turn, the factors that enable the integration of ICT in the training of future teachers are (Aslan \& Zhu, 2017) pedagogical knowledge, pre-service ICT training, and ICT competence. As regards pedagogical knowledge, for the use of emerging technologies to be effective, the following phases should be implemented (Ng'Ambi, 2013): a) set an educational goal; b) anticipate learning outcomes; c) describe the purpose of the activity; d) select the appropriate tools; e) the students create an artefact (i.e., a project); and f) the students reflect on their learning process. In addition, various ICT resources need to be integrated with each other and with innovative methodologies (Markus \& Mentzer, 2014). Service learning, which provides 
real-world experience while providing a service to the community, can be useful for this purpose (Salam et al., 2019). Ideally, the conditions will be created for self-directed and, ultimately, lifelong learning, although few students are actually capable of doing so (Gogh \& Kovari, 2019).

Teachers' digital competence can also facilitate the educational use of ICTs in the classroom depending on the following five factors (Van Den Beemt \& Diepstraten, 2016): ICT usefulness, support received, previous experience, and ICT availability and access outside the classroom. In addition, the teacher's role, the ICT used, the learning objectives, the involvement of people outside the school, the involvement of the students, and the learning outcomes achieved will determine the type of innovation fostered in the classroom, which can either be traditional classrooms where teaching practices are conventional, emerging classrooms in which teaching practices are halfway between more traditional and more innovative ones, or fully innovative classrooms (Bocconi et al., 2013).

The main premise of this article is to improve teacher training to improve education. To this end, we intend to identify the key elements needed to improve both pre-service and in-service teacher education. The study seeks to answer the following question: What are the key elements of teacher education that ensure the successful use of technology and innovative methodologies in the classroom? Through various analyses of interviews with experts with broad experience in different fields of education, the most important points will be identified. These points will be the key elements for improving teacher training.

\section{METHODS}

\section{Design and Sample Selection}

The aim of this study is to identify key elements of teacher training related to the use of innovative technologies and methodologies with a view to improving the educational process. More specifically, it attempts to determine how education can be improved through teacher training. In this regard, teachers must be able to adapt to different contexts and settings using the methodologies and technologies available to them in order to provide their students the best possible education. To this end, eight international experts in education participated in this study. The experts were interviewed about training teachers in how to integrate new technologies in their teaching practice.

To ensure the quality of the data obtained and gain a more comprehensive view of the phenomenon, the informants were selected using a purposive sampling method (Tójar, 2006). The selected informants are all international experts in education with extensive experience who come from different educational backgrounds. Specifically, the sample includes the head of digital education and professor of education at University College London; three professors from the Graduate School of Education at Stanford University; a professor from Singularity University; the head of AltSchool based in Sillicon Valley, California, USA, and one of the most innovative schools in the world; the president of the Best Teachers Institute and author of the book What the Best College Teachers Do; and an education guru and former education advisor from the UK.

\section{Interviews and Procedure}

A qualitative study based on interview data was used to obtain more precise results by the triangulation of methods. In a first phase, was used based on one-hour, semi-structured interviews. In a second phase, was employed to analyse the information in a more subjective manner. To this end, the transcriptions of the interviews with the informants were analysed using text mining and the R programming language. The data were then processed using RStudio statistical software and the "tm" (Feinerer \& Hornik, 2020), "wordcloud" (Fellows, 2018), and "syuzhet" packages (Jockers, 2015). RStudio is a well-known and widely used application in teaching and research since it is a free multiplatform software that provides relevant data for advanced statistical analyses.

The interviews were conducted through different channels: three by videoconference using the Skype platform, four face-to-face interviews in California, and one by email. For the interview conducted via email, the same open-ended questions used in the other interviews were sent to the informant, who responded to 
them in writing. All interviews were recorded and subsequently transcribed for the analysis with the prior consent of the informants. Any personal information that could identify the informants was deleted, and each transcript was assigned a code to guarantee their anonymity. All interviews were then recorded and professionally transcribed.

\section{Data Analysis}

\section{First phase analysis}

To analyse the interview transcripts, a classical content analysis method was used (Bardin, 1996). The method was structured into phases of categorisation, text distribution, and content analysis. The first step of the analysis involved identifying the different categories that emerged from the meta-category (the overarching category) and identifying the key elements for training teachers in the use of innovative technologies and methodologies to improve the educational process. The second step of the analysis was structured around the following questions:

1. What do you think about the development of standards to regulate the digital competence of teachers?

2. What role does initial teacher training at universities play in this educational change?

3. What importance do you attach to the permanent education of teachers?

4. What is the teacher's main challenge in this context of change?

5. What knowledge or practices should be modified and integrated?

The third step complemented the analysis linking the categories with the study objective in order to address the general question guiding the research. It consisted of thoroughly reviewing the passages of the original transcript to ensure that no relevant aspect had been omitted when paraphrasing and summarising the informants' narratives. The categories were distributed in accordance with the study objective and will be used below to structure the presentation of the results.

\section{Second phase analysis}

The data drawn from the interviews were analysed using the RStudio statistics program, as mentioned above. This is a highly versatile program, making it suitable for use in a large number of fields, including education. The software was used to analyse the interview transcripts and obtain relevant data to complement the first phase data. The words used in the transcripts are represented in a word cloud (Heimerl et al., 2014; Lohmann et al., 2015). This process consisted in plotting the words in the transcripts and displaying them in a size proportional to the frequency with which they appear in the responses, thus indicating the elements of greatest importance to the informants. Thus, the most frequent words in the experts' responses are the largest in the chart. The chart enables detecting keywords that help to identify the main ideas behind the responses. Prior to the analysis, irrelevant words, such as fillers, tags, articles, and auxiliary verbs that appear in large numbers in the transcripts and did not provide relevant data for the research, were eliminated from the count. A sentiment analysis of the interviews was also conducted to complement the data obtained through the first phase analysis. Sentiment analysis consists of searching for a series of words associated with certain feelings to identify the emotions produced in the informants in response to the questions. The analysis is done using the NRC Word-Emotion Association lexicon developed by Saif M. Mohammad (Mohammad \& Turney, 2010). The NRC is a list of English words associated with eight basic emotions (anger, anticipation, disgust, fear, joy, sadness, surprise, and trust) and two sentiments (positive and negative) in the experts' responses. This type of analysis is frequently used in research (Liu, 2012; Martinez \& Mateus, 2019; Parmar et al., 2018; Patra et al., 2015; Sasangohar et al., 2020). 


Transcription of
the interviews

Analysis using $R$ language in RStudio
Word cloud created with

the most repeated words

Sentiment analysis of the

words used by the

informants

Figure 2. Sequence of the qualitative analysis

\section{RESULTS}

\section{First Phase Results}

This section provides an overview of international experts in education based on their own experience in training teachers in the use of innovative technologies and methodologies to improve the educational process.

\section{Teacher training}

The informants highlighted that many teachers do not currently know how to use technology in the classroom because teacher training curricula are often just one year in length and cover a large amount of content but leave little room for learning about new technologies. Moreover, training is often limited to learning about the characteristics and potential of technology, rather than how to actually use it to support learning. In this regard, teacher training in ICTs needs to cover aspects such as learning management systems, applications, and collaborative tools, as well as the pedagogical methods to use them. In addition, teachers are permanent novices because new technologies are always emerging.

\section{"Many of our teacher candidates come in and have not been taught using new technologies and part of this is technology is always changing." (Informant 1)}

As the experts pointed out, this may also be due to the fact that teachers acquire initial training and then never retrain. Although initial training provides them with basic skills, there is nothing to demonstrate advanced competence. Teachers need to continually update their skills, knowledge, and experience because many of the tools and competencies they require are constantly changing. In this regard, professional development is important as it enables future teachers to contextualise what they have learned and apply it in specific, real-world settings. This is a fundamental aspect of teacher training because education is about preparing students for the challenges that lay ahead.

\footnotetext{
"Vital! Teachers should always be, first and foremost, lead learners. If education is about helping to prepare our students for the challenges of their future then we need to ensure that our teachers are kept aware of that future. In order to do that, their own skills, knowledge and experiences need to be constantly refreshed." (Informant 6)
}

In order for teachers to adapt to these changes, the experts stress the importance of teachers being aware of the benefits of using new technologies in education. Teachers need to know how new technologies work and why they work so that they can make the necessary modifications and changes to enable them to effectively implement technology in different educational settings. They also need to embrace ongoing action research and have the commitment and confidence to constantly refresh and renew their teaching practices. 
However, the focus should not only be on teachers, but also the heads of schools because they have a significant impact on their educational institutions.

"We can't keep focusing just on teachers because principals are so important like the people at the top so in some of the schools that I think are doing the most exciting things." (Informant 2)

The informants also underlined the importance of challenging the beliefs of future teachers arising from their own education. Training must be practice-based, so that future teachers can integrate and implement new technologies in their school and in society. Indeed, the new generation of teachers requires training that enables them to apply what they have learned in any context. To achieve this, teachers must have not only sufficient knowledge, but also the predisposition to use it.

\begin{abstract}
"We need to remember though that most young people who are wanting to train as teachers have increasingly high levels of digital competence which means that we need to develop programs about how tech supports learning, not about how to use tech. We need also to understand that it will be that generation of teachers who will evolve how we use tech in education, it will not be universities. We need to ensure that training is based on pragmatism and not prescription." (Informant 6)
\end{abstract}

As the interviews revealed, teachers should undergo lifelong learning, because what they are teaching, how they are teaching it, who they are teaching it to, and the tools they are using are constantly changing. It is important to know what tools are currently available, even if they are changing. However, to get people to change, they have to learn to change, and that means recognising the need to improve, which is not always pleasant. According to one of the informants, this fails to meet the four C's of learning: "competence, control, confidence, and comfort." Another aspect reported by the informants is that teachers are intimidated by the possibility of not using new technologies properly, which makes them feel stupid. It is therefore very important to support teachers in ICT use.

\footnotetext{
"Just the intimidation and feeling stupid [for] not knowing technology and also time for when it comes to using it with students, teachers have to understand it themselves." (Informant 3)
}

The experts also underline the importance of permanent training that cannot be limited solely to attending a few workshops. Moreover, teacher trainees need to receive constant feedback from other teachers who supervise their work. Indeed, collaboration between peers is one of the best ways to train future teachers: since both teach the same things, they both get feedback. In addition, goals should be set with specific outcomes that can be monitored and linked to professional development. A good example of this is the Japanese model, where a group of teachers prepare a lesson and test it with different groups of students until they are satisfied that effective learning has been achieved, and then publish the lesson for other teachers to see. If the use of new technologies were also incoporated, the system would be a very powerful. For this to happen, part of the budget needs to be earmarked for investment in this process by both the education authorities and schools:

"Permanent education of teachers, it's absolutely necessary and so that's another thing that I think has to be in all schools' budgets." (Informant 3)

"One model that I really like and think is interesting here is the Japanese model of lesson study which is small groups of teachers who identify one problem that they want to solve in their teaching and then they design a lesson collaboratively and then they test it with different groups of children and refine it and finally they publish it and celebrate I'd I just think that's a very neat model and if there were an aspect to including digital technologies that are the tools in that process I think that would be really powerful." (Informant 1) 
In this regard, the informants emphasise that the best teacher education programmes are those that work with a veteran teacher in the classroom and in a variety of settings. One informant stated that future teachers need to be made to think about what it means to learn by answering four questions. The first question is what people must do intellectually and emotionally to achieve learning; the second, what can go wrong as a stereotype threat; the third, how to create a critical environment where learning is more likely to occur (not simply deliver information), and the fourth, how we as teachers and our students can come to understand our learning progress (assessment).

Another aspect of teachers' learning is to foster curiosity and the need to know, which also provides teachers the necessary tools and skills to continue learning for the rest of their lives (lifelong learning). Creating lifetime learners must be one of the primary goals of any type of education, including that of teachers, who should always be learners. Teachers need to be comfortable with and value the use of technological tools in order to reach students in a different way, and they need to get excited about and learn how to use the tools so that they can then help their students to do the same. The constant development of new technologies facilitates lifelong learning through online tools and resources such as teacher communities on Facebook, Twitter, Pinterest, and other platforms where teachers can learn from each other.

"A lifetime learner, that has to be one of the goals of any education, how you create a lifetime learner [who's] going to continue to grow and continue to try new kinds of things." (Informant 8)

In addition, the informants underscored the importance of involving students in the teacher training process. In this regard, students can help teachers by teaching them about new technologies, although this idea is not always looked well upon by teachers as they often view themselves as the single source of knowledge and are reluctant to be taught or corrected by their students. However, if teachers are receptive to accepting student input, it can transform the traditional passive teaching dynamic into a more active one. In addition, students feel valued because they collaborate with the teacher regardless of age or cultural differences.

"Students can be involved in helping to teach the teachers so it's a different model because sometimes teachers like to be the house of knowledge that impart their knowledge to all of their students." (Informant 4)

According to the informants, it is essential that training and certification be compulsory for all teachers. Teachers must demonstrate that they possess the minimum competencies to be able to teach. Moreover, their teaching skills should be assessed on the basis of research on how human beings learn, so that they are able to use any tool to construct a natural and critical learning environment that facilitates deep learning. Investing in teachers is investing in society because their work is beneficial to society.

"You should be able to show that you've got a minimum competence. I think it is like a driving test, you know you should be able to show that you've got a minimum competence, okay I mean, I, I think if you want to call yourself a professional teacher you shouldn't know the repertoire of tools that are available. [That] doesn't mean you have to use them, okay, but you should know that, well, I could use this tool for doing this particular . . . support this kind of learning, this tool for this particular learning. "(Informant 5)

In order to ensure that teachers possess a minimum of knowledge, one of the most important aspects that the informants mentioned is the need to set standards. This would also mean that teachers would know how to use the latest and most up-to-date tools and feel confident, although the informants acknowledged that this is difficult to put into practice. The complexity of using ICT effectively in the classroom is a challenge because it is not simply a question of teaching with technology. We start by choosing the technology we are going to use and then it has to be mixed in with other more traditional tools. Likewise, the teacher training curriculum should be standards-based, because according to the informants this is the best way to achieve effective results in terms of productivity. 
"The standards-based teacher education curriculum is really the best way of achieving effective outcomes in terms of productivity [...] However I don't think standards are necessarily a panacea. In the UK, a IC standards was used for a few years at the late 1990s, early 2000s, and I think there were about 107 standards and the whole thing became so ... and it lead to evidence and the standards [went] from demon level describing the basic functionality of core technologies all the way through to sophisticated pedagogical routines. They've made them very, very difficult to use in an operational [way]." (Informant 7)

Such standards should be grounded in the educational ethos and aims of the school. Moreover, they should be part of teacher development and competence to ensure that teachers receive the same training in the use of new technologies.

The informants indicated that new teachers have increasingly higher levels of digital competence and that it is the teachers who will change the way technology is used, not the universities. It is therefore necessary to work towards lifelong learning for teachers and inspire them to be leaders.

"It is critical. I don't know that students can respect or feel confident about the implementation of new technologies in their school and also in all of society if the teachers don't have the base knowledge." (Informant 4)

In short, many teachers lack the necessary digital skills due to gaps in their training. For this reason, teacher training must be improved because teachers cannot transfer knowledge and skills they do not have. Training needs to be pragmatic and enable teachers to adapt to any educational context. In addition, permanent training is necessary to ensure that teachers keep up to date. In the process, teachers can count on students for help, as students often have better knowledge of the use of new technologies than teachers. Teaching competencies must also be evaluated to determine teachers' ability to teach and minimum standards should be set to ensure effective teaching practices, which are best measured by pedagogy-based standards.

Based on the above analysis, the following key elements related to teacher training have been identified:

- Teachers require digital skills to be able to transmit them to their students.

- Teacher training must be pragmatic.

- Teachers must be able to adapt to a diversity of educational contexts.

- Teachers must receive ongoing training to ensure that they keep up to date.

- It is important that teachers are supported by their students.

- Teachers' competencies should be assessed based on standards.

- Pedagogy-based standards should be set.

\section{Second Phase Results}

In this section, a second phase analysis is carried out of the experts' responses to the questions on teacher training. First, a word cloud was created using the transcripts of all the interviews. This was followed by a sentiment analysis developed by Mohammad \& Turney (2010) in the informants' responses using 14182 unigrams.

Figure 3 shows the word cloud based on the informants' responses. As can be seen, the words with the largest size are "teacher", "technology", "students", "can", "learning", and "like". These were the most frequently repeated words, particularly "teacher" and "teachers", since they were the main topic of the interviews. Other words such as "can" and "like" also appear more frequently since they are two commonly used verbs in English. However, "teacher", "student", and "technology" are among the words that occur together most frequently, thus highlighting the importance of these three aspects in teacher training. 


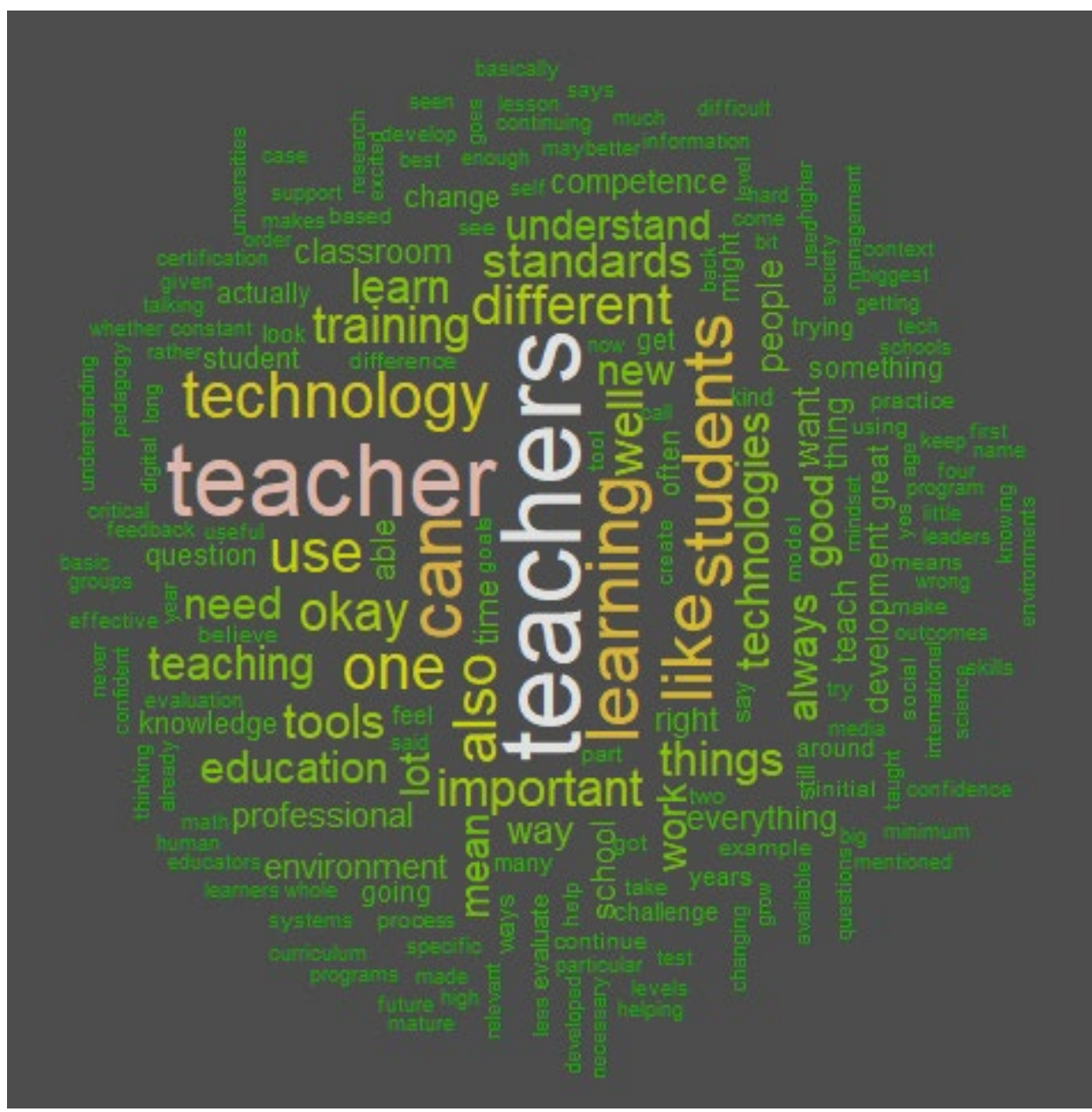

Figure 3. Word cloud for teacher training

The word cloud indicates that the figure of the teacher, students, and technology are key elements in teacher training.

Figure 4 shows a count of the sentiments and emotions that appear in the informants' responses to each of the questions. Firstly, it is important to highlight that positive feelings far outweighed negative ones, which indicates the informants' optimism about the issues discussed. The predominant emotions are "trust" and "anticipation", thus revealing the experts' knowledge and confidence about the different topics addressed in the interview. With regard to the distribution of emotions per question, no major differences were observed. The most noteworthy finding is the low frequency of positive sentiments and the emotion "anticipation" in Question 1, which dealt with the development of standards to regulate the digital competence of teachers. This could indicate that the experts interviewed attach more importance to aspects of teacher training other than the implementation of standards or other types of regulations on digital competence, even though this is a relevant issue in their discourse. In contrast, Question 3, which refers to the importance of permanent training, elicited more negative sentiments and the highest frequency of the emotions "sadness" and "disgust" than in the rest of the questions. This might suggest that the experts believe that permanent teacher training is more complex or difficult to achieve. Although Question 3 showed the highest scores in terms of negative sentiment and negative emotions, negative feelings are still much lower than the positive ones in this question. 


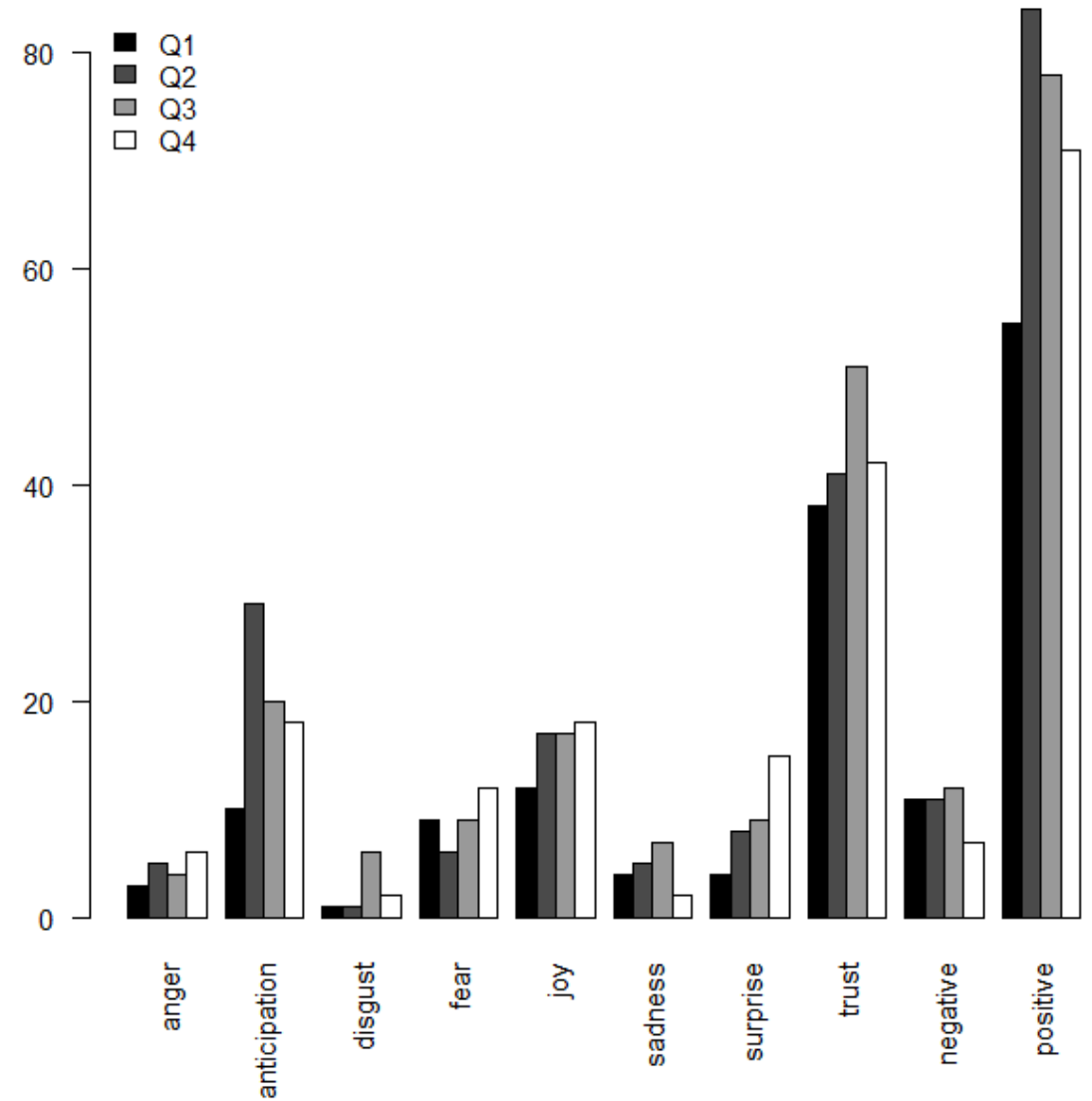

Figure 4. Analysis of emotions based on the NRC lexicon by question

The results of the sentiment analysis identified the following key elements of teacher training:

- The need to improve teacher training.

- The difficulty of implementing permanent training.

- Standards and norms are not the most important elements of teacher training.

\section{DISCUSSION}

As our study has shown, the most important factor to achieve educational change is teacher training (Geer et al., 2017), followed by curricula that engage students not only in their own learning, but in society as a whole (Broadbent \& Papadopoulos, 2012). The figure of the teacher appears as a key element in educational change both in the interviews with the experts and the second phase analyses of their transcripts. Consequently, special emphasis must be placed on teacher training, which is decisive for their future performance in the classroom. However, teacher training is currently inadequate (Fernández-Cruz \& Fernández-Díaz, 2016), as teachers are often not trained in new technologies. One of the main findings of our research points to the importance of teachers being taught how to use technologies in a practical way (Pérez-Escoda et al., 2016) and to support their teaching practice. The experts highlight the importance of using real-life experiences in teacher training with the support of veteran teachers. According to previous research, teachers are still only taught about the properties and characteristics of technology (Barak, 2014). This means that new technologies are often not used appropriately in schools, thus explaining why both the informants and previous studies speak of the need for pre-service teachers to certify minimum digital competencies in order to become teachers (Aslan \& Zhu, 2017). Equally, certified standards would make it possible to verify teachers' advanced competencies by recognising their work.

The informants agreed that although initial teacher training entails the mastery of basic competencies required for teaching practice, the mastery of advanced competencies must also be certified. However, as 
initial teacher training is lacking, the level of initial competencies acquired during training is insufficient and not a guarantee that teachers have, in fact, acquired basic skills. Therefore, the use of standards could also be included in their training to confirm that trained teachers have the necessary skills to be successful in their profession. Standards-based curricula would be the most effective way to achieve this (Almerich et al., 2016) so that all teachers receive the same level of training and those who obtain an advanced level are given due recognition. From the study it is clear that standards should be based on each school's pedagogical approach and goals. However, it is important to note that establishing a large number of standards is also counterproductive due to the difficulty of applying them in practice. This difficulty may have influenced the low level of optimism reflected by the experts in the first phase analysis on the implementation of standards to measure teaching staff skills. As mentioned, the informants highlight that teacher training requires a pragmatic not a theoretical approach (Siddiq et al., 2016). Therefore, training future teachers with a veteran teacher in the classroom in a variety of settings is the best option (Van Acker et al., 2013). In addition, lifelong learning and supporting and even inspiring teachers to be leaders is paramount to their success. Nonetheless, the informants highlighted the complexity involved in doing this, because teachers are permanent novices since new technologies are constantly emerging and changing the way they work. At the same time, however, ICTs can facilitate lifelong learning since teachers can train online (Laurillard, 2016) and provide feedback to each other in online communities (Tondeur et al., 2019). However, in order to do so, teachers must have a minimum knowledge of new technologies to successfully carry out online training and keep up to date independently on a permanent basis. Minimum skills must be acquired during initial training to ensure teachers can perform their functions autonomously. This is particularly important in cases where teachers are teaching in rural or isolated areas with limited peer support and material resources. They need to use the internet to create resources, interact with other teachers, participate in online training, and keep up to date. Heads of schools also play an important role in coordinating teachers, as a teacher who works alone in his or her classroom will not be able to bring about educational change (Tondeur et al., 2008). The experts stress the importance of supporting and motivating teachers.

An additional finding of the study is that some teachers are intimidated by new technologies in the classroom out of the fear that their students will know more than they do (Cairns \& Malloch, 2017). Sometimes this insecurity makes them feel awkward in front of their students (Wang et al., 2014) and teachers need to feel confident (Archer et al., 2014) and valued (Drossel et al., 2017). Therefore, the lack of adequate training for future teachers leads to the lack of skills, which ultimately leads to insecurity when it comes to implementing and experimenting with new technologies in the classroom. This means that even if technological devices are available, improvements in education will not be achieved. In this regard, another important factor the informants mentioned is the collaboration of students in the implementation of new technologies in the classroom (Thieman \& Cevallos, 2017), as students often have more knowledge of new technologies than teachers (Cairns \& Malloch, 2017; Wang et al., 2014). Students need to be involved, assigned a role, and given responsibility, and empathy is essential for students to develop knowledge. Teamwork also prevents them from isolating themselves when using new technologies. The role of parents and collaboration with families is equally important in the regard. External help, especially from students, could boost the implementation of new technologies in the classroom. This would enable teachers to see students as helping them to use classroom technologies rather than as evaluators who question their work. The feedback between teachers and students in the implementation of new technologies takes pressure off teachers and enables them to feel more at ease. It also gives students a greater role in their own learning process. Moreover, student participation would faciliate teachers' continuous learning, as students are, in general, highly proficient in new technologies (Cairns \& Malloch, 2017; Wang et al., 2014). In turn, it would also change the traditional role of the teacher from that of tranferer of knowledge to that of guide who accompanies students in their learning process. This role is endorsed in the most innovative methodologies and is referred to as active learning methodologies, which includes project-based learning. The importance of students in the learning process is reflected in both the international experts' responses and the analysis of the words used.

Additionally, the word count revealed that the informants are concerned about two key aspects of teacher training, namely the importance of using technology in the classroom and taking students into account in the learning process. These data coincide with thoses collected in the interviews. Currently, much importance is 
attached to student-centred learning processes (García-Carmona, 2015) and students as collaborators in the implementation of new technologies in the classroom (Espigares-Pinazo et al., 2020). Moreover, the sentiment analysis of the responses to the questions showed higher scores for positive feelings than for negative ones, thus indicating the positive attitude and confidence of the experts regarding the issues raised. The question on initial teacher training showed the highest positive score, while the question on standards for regulating teachers' digital competence showed the lowest, although the score remained high. This question obtained the lowest score for positive sentiment and the emotions of confidence and anticipation, coinciding with the opinion expressed by the experts on the difficulty of implementing standards. This could indicate that the experts believe it would be easier to improve teacher competencies in initial teacher training than to assess their competencies through standards because of the complexities involved.

\section{CONCLUSIONS}

The data obtained in the second phase analysis coincide with and support the data of the first phase analysis. The study shows that teachers are the most important element for educational change to occur and must therefore receive pragmatic training to be able to adapt to any educational context or setting. Training needs to be ongoing because the conditions in which teachers work (i.e. students, technology, the classroom, etc.) are constantly changing and they need to keep up to date to provide their students a quality education. To achieve this, however, teachers require support and must be motivated. Much of this support can come from the students themselves if they are given an active role in their learning process, are motivated, and made to feel useful. The support of heads of schools is also essential so that the changes involve the whole school and are not limited to a single classroom. As mentioned above, in order to determine whether teachers are up to date and really have digital teaching skills, standards must be set. In short, teachers are a key element in the teaching-learning process and play an essential role in the proper integration of ICTs in the classroom. Therefore, to benefit their students and the rest of society, they must be provided quality training focused on teaching practice. Several of the above elements coincide with those of the SQD model (Tondeur et al., 2019).

\section{LIMITATIONS AND FUTURE RESEARCH}

This study has some limitations. The main limitation was the impossibility of conducting all the interviews face-to-face, as interviews of this type are usually conducted in a more relaxed atmosphere and informants tend to provide more information. The interviews conducted by videoconference, although similar to faceto-face interviews, are actually somewhat colder and more direct. Finally, the interview conducted by email was the most restrained and the responses were collected directly in writing. Had the interview been carried out in person, it would have been possible to obtain a greater amount of information. Nonetheless, thanks to digital media, we have been able to interview leading professionals who have contributed their knowledge and experience to this study.

Future research could focus on the degree to which each of the key elements impacts on different educational contexts. This would allow us to observe whether some elements are more relevant in certain contexts and need to be improved. A specific educational context could also be evaluated and key elements could be reinforced to ascertain the degree of educational improvement. In summary, with the aim of facilitating educational change, further research could be carried out from a more practical approach to expand on the findings presented in this study.

\footnotetext{
Author contributions: All authors were involved in concept, design, collection of data, interpretation, writing, and critically revising the article. All authors approve final version of the article.

Funding: The authors received no financial support for the research and/or authorship of this article.

Declaration of interest: Authors declare no competing interest.

Data availability: Data generated or analysed during this study are available from the authors on request.
} 


\section{REFERENCES}

Akayoglu, S., Satar, H. M., Dikilitas, K., Cirit, N. C., \& Korkmazgil, S. (2020). Digital literacy practices of Turkish pre-service EFL teachers. Australasian Journal of Educational Technology, 36(1), 85-97. https://doi.org/10.14742/ajet.4711

Almerich, G., Orellana, N., Suárez-Rodríguez, J., \& Díaz-García, I. (2016). Teachers' information and communication technology competences: A structural approach. Computers and Education, 100, 110125. https://doi.org/10.1016/j.compedu.2016.05.002

Archer, K., Savage, R., Sanghera-Sidhu, S., Wood, E., Gottardo, A., \& Chen, V. (2014). Examining the effectiveness of technology use in classrooms: A tertiary meta-analysis. Computers and Education, 78, 140-149. https://doi.org/10.1016/j.compedu.2014.06.001

Aslan, A., \& Zhu, C. (2017). Investigating variables predicting turkish pre-service teachers' integration of ICT into teaching practices. British Journal of Educational Technology, 48(2), 552-570. https://doi.org/10.1111/bjet.12437

Barak, M. (2014). Closing the gap between attitudes and perceptions about ICT-enhanced learning among pre-service STEM teachers. Journal of Science Education and Technology, 23(1), 1-14. https://doi.org/10.1007/s10956-013-9446-8

Baran, E., \& Uygun, E. (2016). Putting technological, pedagogical, and content knowledge (TPACK) in action: An integrated TPACK-design-based learning (DBL) approach. Australasian Journal of Educational Technology, 32(2). https://doi.org/10.14742/ajet.2551

Bingimlas, K. A. (2009). Barriers to the successful integration of ICT in teaching and learning environments: A review of the literature. Eurasia Journal of Mathematics, Science and Technology Education, 5(3), 235245. https://doi.org/10.12973/ejmste/75275

Bocconi, S., Kampylis, P., \& Punie, Y. (2013). Framing ICT-enabled Innovation for Learning: The case of oneto-one learning initiatives in Europe. European Journal of Education, 48(1), 113-130. https://doi.org/10.1111/ejed.12021

Bozalek, V., Gachago, D., Alexander, L., Watters, K., Wood, D., Ivala, E., \& Herrington, J. (2013). The use of emerging technologies for authentic learning: A south african study in higher education. British Journal of Educational Technology, 44(4), 629-638. https://doi.org/10.1111/bjet.12046

Broadbent, R., \& Papadopoulos, T. (2012). Getting wired@collingwood: An ICT project underpinned by action research. Community Development Journal, 47(2), 248-265. https://doi.org/10.1093/cdj/bsq061

Brun, M., \& Hinostroza, J. E. (2014). Learning to become a teacher in the 21st century: ICT integration in initial teacher education in chile. Educational Technology and Society, 17(3), 222-238. http://www.jstor.org/stable/jeductechsoci.17.3.222

Cairns, L., \& Malloch, M. (2017). Computers in education: The impact on schools and classrooms. In: E. Maclean (Ed.), Life in schools and classrooms. Education in the Asia-Pacific Region: Issues, concerns and prospects (vol. 38). Springer, Singapore. https://doi.org/10.1007/978-981-10-3654-5_36

Charbonneau-Gowdy, P. (2015). It takes a community to develop a teacher: Testing a new teacher education model for promoting ICT in classroom teaching practices in chile. Electronic Journal of E-Learning, 13(4), 237-249.

Chen, F., Gorbunova, N. V., Masalimova, A. R., \& Bírová, J. (2017). Formation of ICT-competence of future university school teachers. Eurasia Journal of Mathematics, Science and Technology Education, 13(8), 4765-4777. https://doi.org/10.12973/eurasia.2017.00963a 
Cuban, L., Kirkpatrick, H., \& Peck, C. (2001). High access and low use of technologies in high school classrooms: Explaining an apparent paradox. American Educational Research Journal, 38(4), 813-834. https://doi.org/10.3102/00028312038004813

Drajati, N. A., Rakerda, H., Sulistyawati, H., Nurkamto, J., \& Ilmi, M. (2021). Investigating the adoption of TPACK-21CL by English pre-service teachers in a COVID-19 teaching practicum. Indonesian Journal of Applied Linguistics, 11(1), 124-133. https://doi.org/10.17509/ijal.v11i1.34625

Drent, M., \& Meelissen, M. (2008). Which factors obstruct or stimulate teacher educators to use ICT innovatively? Computers and Education, 51(1), 187-199. https://doi.org/10.1016/j.compedu.2007.05.001

Drossel, K., Eickelmann, B., \& Gerick, J. (2017). Predictors of teachers' use of ICT in school - the relevance of school characteristics, teachers' attitudes and teacher collaboration. Education and Information Technologies, 22(2), 551-573. https://doi.org/10.1007/s10639-016-9476-y

Durães, D., Jiménez, A., Bajo, J., \& Novais, P. (2016). Monitoring level attention approach in learning activities. In T. Di Mascio, M. Caporuscio, F. De la Prieta, P. Vittorini, R. Gennari, \& J. G. Rodriguez (Eds.), Methodologies and intelligent systems for technology enhanced learning (pp. 33-40). Springer Verlag. https://doi.org/10.1007/978-3-319-40165-2_4

Eger, J. M., \& Maggipinto, A. (2010). Technology as a tool of transformation: E-cities and the rule of law. In A. D'Atri \& D. Saccà (Eds.), Information systems: People, organizations, institutions, and technologies ItAIS: The Italian association for information systems (pp. 23-30). https://doi.org/10.1007/978-3-79082148-2_4

Espigares-Pinazo, M. J., Bautista-Vallejo, J. M., \& García-Carmona, M. (2020). Evaluations in the moodlemediated music teaching-learning environment. Technology, knowledge and learning. https://doi.org/10.1007/s10758-020-09468-0

Estacio, E. V., Whittle, R., \& Protheroe, J. (2017). The digital divide: Examining socio-demographic factors associated with health literacy, access and use of internet to seek health information. Journal of Health Psychology, 24(12), 1668-1675. https://doi.org/10.1177/1359105317695429

Feinerer I., \& Hornik K. (2020). tm: Text Mining Package. R package version 0.7-8. https://CRAN.Rproject.org/package $=$ tm

Fellows I. (2018). wordcloud: Word Clouds. $R$ package version 2.6. https://CRAN.Rproject.org/package $=$ wordcloud

Fernández-Cruz, F., \& Fernández-Díaz, M. (2016). Generation z's teachers and their digital skills. Comunicar, 24(46), 97-105. https://doi.org/10.3916/C46-2016-10

Foronda, C. L., Alfes, C. M., Dev, P., Kleinheksel, A. J., Nelson, D. A., O’Donnell, J. M., \& Samosky, J. T. (2017). Virtually nursing: Emerging technologies in nursing education. Nurse Educator, 42(1), 14-17. https://doi.org/10.1097/NNE.0000000000000295

Garba, S. A., \& Yusuf, B. (2016). Digital technologies and emerging educational objectives: The need for transformational changes in teacher education and training. In I. H. Amzat, \& B. Yusuf (Eds.), Fast forwarding higher education institutions for global challenges: Perspectives and approaches (pp. 4760). Springer Singapore. https://doi.org/10.1007/978-981-287-603-4_5

García-Carmona, M. (2015). La educación actual: retos para el profesorado [Education today: challenges for teachers]. Revista Ibero-Americana de Estudos em Educação, 10(4), 1199-1211 https://doi.org/10.21723/riaee.v10i4.8262

García-Valcárcel, A., Basilotta, V., \& López García, C. (2014). ICT in collaborative learning in the classrooms of primary and secondary education. Comunicar, 21(42), 65-74. https://doi.org/10.3916/C42-2014-06 
Geer, R., White, B., Zeegers, Y., Au, W., \& Barnes, A. (2017). Emerging pedagogies for the use of iPads in schools. British Journal of Educational Technology, 48(2), 490-498. https://doi.org/10.1111/bjet.12381

Gil-Flores, J., Rodríguez-Santero, J., \& Torres-Gordillo, J. (2017). Factors that explain the use of ICT in secondary-education classrooms: The role of teacher characteristics and school infrastructure. Computers in Human Behavior, 68, 441-449. https://doi.org/10.1016/j.chb.2016.11.057

Gogh, E., \& Kovari, A. (2019). Metacognition and Lifelong Learning: A survey of secondary school students. In 9th IEEE International Conference on Cognitive Infocommunications, CogInfoCom 2018 - Proceedings (pp. 271-276). https://doi.org/10.1109/CogInfoCom.2018.8639961

Guillén-Guerrero, G., \& Molina, O. A. M. (2019). Impacto de la capacitación docente con formato b-learning sobre la metodología docente y evaluativa de los profesores [The impact of a b-learning teacher training on the teachers teaching and evaluation methodology]. RISTI - Revista Iberica de Sistemas $e$ Tecnologias de Informacao, 2019(E21), 166-175.

Hambira, N., Lim, C. K., \& Tan, K. L. (2017). Emotional and cultural impacts of ICT on learners: A case study of opuwo, Namibia. AIP Conference Proceedings, 1891, 020048. https://doi.org/10.1063/1.5005381

Harris, J., Mishra, P., \& Koehler, M. (2009). Teachers' technological pedagogical content knowledge and learning activity types: Curriculum-based technology integration refrained. Journal of Research on Technology in Education, 41(4), 393-416. https://doi.org/10.1080/15391523.2009.10782536

Heimerl, F., Lohmann, S., Lange, S., \& Ertl, T. (2014). Word cloud explorer: Text analytics based on word clouds. In 2014 47th Hawaii International Conference on System Sciences (pp. 1833-1842). IEEE Computer Society. https://doi.org/10.1109/HICSS.2014.231

Hohlfeld, T. N., Ritzhaupt, A. D., Barron, A. E., \& Kemker, K. (2008). Examining the digital divide in K-12 public schools: Four-year trends for supporting ICT literacy in florida. Computers and Education, 51(4), 16481663. https://doi.org/10.1016/j.compedu.2008.04.002

Hsu, S., \& Kuan, P. (2013). The impact of multilevel factors on technology integration: The case of taiwanese grade 1-9 teachers and schools. Educational Technology Research and Development, 61(1), 25-50. https://doi.org/10.1007/s11423-012-9269-y

Jockers, M. L. (2015). Syuzhet: Extract sentiment and plot arcs from text. https://github.com/mjockers/syuzhet

Jones, J., \& Pal, J. (2015). (2015). Counteracting dampeners: Understanding technology amplified capabilities of people with disabilities in Sierra Leone. ICTD '15: Proceedings of the Seventh International Conference on Information and Communication Technologies and Development, 15, 6. https://doi.org/10.1145/2737856.2738025

Klaassen, R., De Vries, P., loannides, M. G., \& Papazis, S. (2017). (2017). Tipping your toe in the 'emerging technologies' pond from an educational point of view. In Proceedings of the 45th SEFI Annual Conference 2017 - Education Excellence for Sustainability, SEFI 2017 (pp. 1190-1197). http://resolver.tudelft.nl/uuid:70760a25-2ec0-434d-a066-711dd98ccfe5

Koh, J. H. L., Woo, H. -., \& Lim, W. -. (2013). Understanding the relationship between singapore preservice teachers' ICT course experiences and technological pedagogical content knowledge (TPACK) through ICT course evaluation. Educational Assessment, Evaluation and Accountability, 25(4), 321-339. https://doi.org/10.1007/s11092-013-9165-y

Kozanitis, A., Ménard, L., \& Boucher, S. (2018). Capacitación y acompañamiento pedagógico de profesores universitarios noveles: efectos sobre el uso de estrategias de enseñanza [Continuous development and education follow-up of new university professors: Effects on the use of teaching strategies] Praxis Educativa, 13(2), 294-311. https://doi.org/10.5212/PraxEduc.v.13i2.0003 
Laurillard, D. (2016). The educational problem that MOOCs could solve: Professional development for teachers of disadvantaged students. Research in Learning Technology, 24, 29369. https://doi.org/10.3402/rlt.v24.29369

Liu, B. (2012). Sentiment analysis and opinion mining. https://doi.org/10.2200/S00416ED1V01Y201204HLT016

Lohmann, S., Heimerl, F., Bopp, F., Burch, M., \& Ertl, T. (2015). Concentri cloud: Word cloud visualization for multiple text documents. In Proceedings of the International Conference on Information Visualisation, 2015-September (pp. 114-120). https://doi.org/10.1109/iV.2015.30

Manzoor, A. (2016). Emerging role of technology in health education for youth. In Public health and welfare: Concepts, methodologies, tools, and applications (pp. 1447-1464). IGI Global. https://doi.org/10.4018/978-1-5225-1674-3.ch068

Marcelo, C., Yot, C., \& Mayor, C. (2015). University teaching with digital technologies. Comunicar, 23(45), 117-124. https://doi.org/10.3916/C45-2015-12

Markus, M. L., \& Mentzer, K. (2014). Foresight for a responsible future with ICT. Information Systems Frontiers, 16(3), 353-368. https://doi.org/10.1007/s10796-013-9479-9

Martínez Zárate, J., \& Mateus Santiago, S. (2019). Sentiment Analysis Through Machine Learning for the Support on Decision-Making in Job Interviews. In C. Stephanidis (Ed.), HCl International 2019 - Late Breaking Papers. HCII 2019. Lecture Notes in Computer Science (vol. 11786, pp. 202-213). Springer, Cham. https://doi.org/10.1007/978-3-030-30033-3_16

Mendonça, S., Crespo, N., \& Simões, N. (2015). Inequality in the network society: An integrated approach to ICT access, basic skills, and complex capabilities. Telecommunications Policy, 39(3-4), 192-207. https://doi.org/10.1016/j.telpol.2014.12.010

Midgley, G. (1993). Three models of IT training for people with disabilities. Information Technology Training for People with Disabilities, 36-47.

Mohammad, S., \& Turney, P. (2010, June). Emotions evoked by common words and phrases: Using mechanical turk to create an emotion lexicon. In Proceedings of the NAACL HLT 2010 workshop on computational approaches to analysis and generation of emotion in text (pp. 26-34).

Munns, G., Sawyer, W., \& Cole, B. (2013). Exemplary teachers of students in poverty. In Exemplary teachers of students in poverty (pp. 1-208). Taylor and Francis. https://doi.org/10.4324/9780203076408

Nemiña, R. E. (2018). Las comunidades de aprendizaje como estrategia de desarrollo profesional de docentes de Educación física [Learning communities as a strategy for the professional development of Physical education teachers]. Estudios Pedagogicos, 44(1), 259-278. https://doi.org/10.4067/S071807052018000100259

Ng'Ambi, D. (2013). Effective and ineffective uses of emerging technologies: Towards a transformative pedagogical model. British Journal of Educational Technology, 44(4), 652-661. https://doi.org/10.1111/bjet.12053

Nikolopoulou, K., \& Gialamas, V. (2015a). Barriers to the integration of computers in early childhood settings: Teachers' perceptions. Education and Information Technologies, 20(2), 285-301. https://doi.org/10.1007/s10639-013-9281-9

Nikolopoulou, K., \& Gialamas, V. (2015b). ICT and play in preschool: Early childhood teachers' beliefs and confidence. International Journal of Early Years Education, 23(4), 409-425. https://doi.org/10.1080/09669760.2015.1078727 
Park, S. R., Choi, D. Y., \& Hong, P. (2015). Club convergence and factors of digital divide across countries. Technological Forecasting and Social Change, 96, 92-100. https://doi.org/10.1016/j.techfore.2015.02.011

Parmar, M., Maturi, B., Dutt, J. M., \& Phate, H. (2018). Sentiment Analysis on Interview Transcripts: An application of NLP for Quantitative Analysis. In 2018 International Conference on Advances in Computing, Communications and Informatics, ICACCI 2018 (pp. 1063-1068). https://doi.org/10.1109/ICACCI.2018.8554498

Patra, B. G., Ghosh, N., Das, D., \& Bandyopadhyay, S. (2015). Identifying temporal information and tracking sentiment in cancer patients' interviews. In Computational Linguistics and Intelligent Text Processing (CICLing 2015) (pp. 180-188). LNCS. https://doi.org/10.1007/978-3-319-18117-2_14

Pelgrum, W. J. (2001). Obstacles to the integration of ICT in education: Results from a worldwide educational assessment. Computers and Education, 37(2), 163-178. https://doi.org/10.1016/S03601315(01)00045-8

Pérez-Escoda, A., Castro-Zubizarreta, A., \& Fandos-Igado, M. (2016). Digital skills in the Z generation: Key questions for a curricular introduction in primary school. Comunicar, 24(49), 71-79. https://doi.org/10.3916/C49-2016-07

Postareff, L., Lindblom-Ylänne, S., \& Nevgi, A. (2007). The effect of pedagogical training on teaching in higher education. Teaching and Teacher Education, 23(5), 557-571. https://doi.org/10.1016/j.tate.2006.11.013

Quintana, M. G. B., \& Zambrano, E. P. (2014). E-mentoring: The effects on pedagogical training of rural teachers with complex geographical accesses. Computers in Human Behavior, 30, 629-636. https://doi.org/10.1016/j.chb.2013.07.042

Resta, P., \& Laferrière, T. (2015). Digital equity and intercultural education. Education and Information Technologies, 20(4), 743-756. https://doi.org/10.1007/s10639-015-9419-z

Roig-Vila, R., Mengual-Andrés, S., \& Quinto-Medrano, P. (2015). Primary teachers' technological, pedagogical and content knowledge. Comunicar, 23(45), 151-159. https://doi.org/10.3916/C45-2015-16

Salam, M., Awang, D. N., Ibrahim, D. H. A., \& Farooq, M. S. (2019). Technology integration in service-learning pedagogy: A holistic framework. Telematics and Informatics, 38, 257-273. https://doi.org/10.1016/j.tele.2019.02.002

Sasangohar, F., Dhala, A., Zheng, F., Ahmadi, N., Kash, B., \& Masud, F. (2021). Use of telecritical care for family visitation to ICU during the COVID-19 pandemic: An interview study and sentiment analysis. BMJ Quality and Safety, 30, 715-721. https://doi.org/10.1136/bmjqs-2020-011604

Schmidt, D. A., Baran, E., Thompson, A. D., Mishra, P., Koehler, M. J., \& Shin, T. S. (2009). Technological pedagogical content knowledge (Track): The development and validation of an assessment instrument for preservice teachers. Journal of Research on Technology in Education, 42(2), 123-149. https://doi.org/10.1080/15391523.2009.10782544

Siddiq, F., Hatlevik, O. E., Olsen, R. V., Throndsen, I., \& Scherer, R. (2016). Taking a future perspective by learning from the past - A systematic review of assessment instruments that aim to measure primary and secondary school students' ICT literacy. Educational Research Review, 19, 58-84. https://doi.org/10.1016/j.edurev.2016.05.002

Tallvid, M. (2016). Understanding teachers' reluctance to the pedagogical use of ICT in the 1:1 classroom. Education and Information Technologies, 21(3), 503-519. https://doi.org/10.1007/s10639-014-9335-7

Thieman, G. Y., \& Cevallos, T. (2017). Promoting educational opportunity and achievement through 1:1 iPads. International Journal of Information and Learning Technology, 34(5), 409-427. https://doi.org/10.1108/IJILT-06-2017-0047 
Tójar Hurtado, J. C. (2006). Investigación cualitativa: Comprender y actuar [Qualitative research: Understand and act]. La Muralla. http://digital.casalini.it/9788471339393

Tondeur, J., Scherer, R., Baran, E., Siddiq, F., Valtonen, T., \& Sointu, E. (2019). Teacher educators as gatekeepers: Preparing the next generation of teachers for technology integration in education. British Journal of Educational Technology, 50(3), 1189-1209. https://doi.org/10.1111/bjet.12748

Tondeur, J., Van Braak, J., Siddiq, F., \& Scherer, R. (2016). Time for a new approach to prepare future teachers for educational technology use: Its meaning and measurement. Computers and Education, 94, 134150. https://doi.org/10.1016/j.compedu.2015.11.009

Tondeur, J., van Keer, H., van Braak, J., \& Valcke, M. (2008). ICT integration in the classroom: Challenging the potential of a school policy. Computers and Education, 51(1), 212-223. https://doi.org/10.1016/j.compedu.2007.05.003

Uluyol, C., \& Sahin, S. (2016). Elementary school teachers' ICT use in the classroom and their motivators for using ICT. British Journal of Educational Technology, 47(1), 65-75. https://doi.org/10.1111/bjet.12220

Valtonen, T., Kukkonen, J., Kontkanen, S., Sormunen, K., Dillon, P., \& Sointu, E. (2015). The impact of authentic learning experiences with ICT on pre-service teachers' intentions to use ICT for teaching and learning. Computers and Education, 81, 49-58. https://doi.org/10.1016/j.compedu.2014.09.008

Van Acker, F., van Buuren, H., Kreijns, K., \& Vermeulen, M. (2013). Why teachers use digital learning materials: The role of self-efficacy, subjective norm and attitude. Education and Information Technologies, 18(3), 495-514. https://doi.org/10.1007/s10639-011-9181-9

Van Den Beemt, A., \& Diepstraten, I. (2016). Teacher perspectives on ICT: A learning ecology approach. Computers and Education, 92-93, 161-170. https://doi.org/10.1016/j.compedu.2015.10.017

Wahyuni, I., Zaenuri, Wardono, Sukestiyarno, Y. L., Waluya, S. B., Nuriana, \& Aminah, N. (2021). Design of instrument Technological Pedagogic Content Knowledge (TPACK) for prospective mathematics teachers. Journal of Physics: Conference Series, 1918(4), 042097. https://doi.org/10.1088/1742$6596 / 1918 / 4 / 042097$

Wang, S., Hsu, H., Campbell, T., Coster, D. C., \& Longhurst, M. (2014). An investigation of middle school science teachers and students use of technology inside and outside of classrooms: Considering whether digital natives are more technology savvy than their teachers. Educational Technology Research and Development, 62(6), 637-662. https://doi.org/10.1007/s11423-014-9355-4

Williams, P., Jamali, H. R., \& Nicholas, D. (2006). Using ICT with people with special education needs: What the literature tells us. Aslib Proceedings: New Information Perspectives, 58(4), 330-345. https://doi.org/10.1108/00012530610687704

Wilson, M., Scalise, K., \& Gochyyev, P. (2015). Rethinking ICT literacy: From computer skills to social network settings. Thinking Skills and Creativity, 18, 65-80. https://doi.org/10.1016/j.tsc.2015.05.001

Zimmermann, F., Melle, I., \& Huwer, J. (2021). Developing prospective chemistry teachers' TPACK-A comparison between students of two different universities and expertise levels regarding their TPACK self-efficacy, attitude, and lesson planning competence. Journal of Chemical Education, 98(6), 18631874. https://doi.org/10.1021/acs.jchemed.0c01296

Correspondence: José Manuel García-Vandewalle García. Department of Didactics and School Organization, University of Granada, Spain. E-mail: jgvandewalleg@gmail.com 